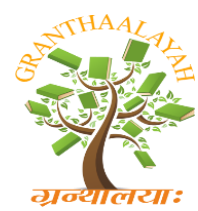

INTERNATIONAL JOURNAL OF RESEARCH GRANTHAALAYAH A knowledge Repository

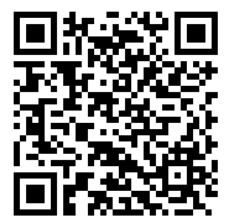

Management

\title{
THE MUTUAL INFLUENCE OF INVESTMENT IN EDUCATION ON ECONOMIC DEVELOPMENT IN INDIA
}

\author{
Dr. N. Savitha ${ }^{* 1}$, Dr. M. John Sundar David ${ }^{2}$ \\ ${ }^{* 1}$ Assistant Professor, VIT University, Vellore - 632 014, INDIA \\ ${ }^{2}$ Professor \& Dean, VIT University, Vellore - 632 014, INDIA
}

\begin{abstract}
"Education" as a key determinant of economic development and growth is believed to be the central focus of many emerging economies since they have managed to restructure their entire economic policies towards enhancing education (especially higher education) to attain economic development and growth at global standard in the recent past. Keeping all the facts in mind, an attempt has been made in this paper to study the relationship between education and economic development in general and India in particular. India has the 3rd largest higher education system in the world in terms of education after Chine and the US. For the purpose of the study, an extensive survey of earlier studies on this ground has been surveyed.

On the basis of the assertion made by the earlier studies and evidence, the present study envisages the importance of investment in higher education and human capital to attain sustainable economic development.
\end{abstract}

Keywords:

Higher Education, Economic growth and development.

Cite This Article: Dr. N. Savitha, and Dr. M. John Sundar David, "THE MUTUAL INFLUENCE OF INVESTMENT IN EDUCATION ON ECONOMIC DEVELOPMENT IN INDIA" International Journal of Research - Granthaalayah, Vol. 4, No. 1 (2016): 80-85.

\section{INTRODUCTION}

The idea of "education endorses economic development and growth" is the driving force of many developed and developing economies to invest in the educational sector. Especially, higher education is an important form of investment in human capital development. In fact, it can be regarded as a high level or a specialized form of human capital, which has a significant contribution towards the economic development of almost all parts of the globe. In the words of Castells (1994:15), it is rightly regarded as the 'engine of development in the new world economy'.

Education not only augments individual earnings, but also has a major share in national income generation. Because of its significant role in economic development, every economy (including 
India) shows more interest and as well as concerns towards education in its national budgeting. The application behind economic growth through education is not a new topic in the current discussion because investment in education has been regarded as one of the major determinants of economic growth even in the times of Adam Smith. In the earlier literature 'land' was considered as a major source of income and wealth generation in agricultural societies; 'capital and machinery' were regarded as the source of wealth generation in industrial societies; while in the case of information societies, knowledge augments economic growth and development. Since higher education is the source of knowledge production and dissemination, every society can utilize the expertise to attain growth and development. More importantly, sustained economic development of any economy is possible only if it concentrates its economic policies towards enhancing and developing the higher education of its human capital.

Education and economic development are two sides of a coin, an economy should give equal weight to each other. It is a debatable topic because of its two-way causatives. Many arguments have been raised by scholars, academicians and policy makers that, which contributes to which? Is it education which drives the economy to a developmental path; or vice versa.

Recently, in many published research articles and daily newspapers stresses on the facts that, economic growth currently depends on the capacity to produce knowledge-based goods of a country. However, the future of knowledge economies depends more on their capacity to produce knowledge through research and development rather than on knowledge-based goods. Hence, knowledge economies place greater value and accord higher priority to the production and distribution of knowledge. Higher education institutions are major sources of knowledge production which are the vital requirement of an effective human capital. Hence, an attempt has been made in the subsequent sections of this paper to lay an outline of the Indian higher educational system and its significant contribution towards economic development and growth.

\section{INDIAN HIGHER EDUCATION SECTOR}

The population of India has begun to appreciate the value of education in a global economy and has demonstrated an increased willingness to pay for quality education and more students are now opting for higher education after school.

India has the $3^{\text {rd }}$ largest higher education system in the world in terms of enrolments after China and the US. The number of students enrolled in the universities and colleges were 16 million during the academic year 2010-11. This does not include enrolment in higher education offered through ODL. India not only has the largest student enrollment but also in terms of a number of institutions it is listed on the top. Indian educational sector is the second largest employment generator in the country, and the higher educational system comprises 610 state and central Universities and 33,023 colleges throughout the nation which accounts approximately $\$ 13$ billion expenditure every year.

\section{DETERMINANTS OF GROWTH IN HIGHER EDUCATION SECTOR IN INDIA}

There has been phenomenal growth of higher education in India since Independence. The number of Universities has increased 34 times from 20 in 1950 to 677 in 2014. The sector boasts 
of 45 Central Universities of which 40 are under the purview of Ministry of Human Resource Development, 318 State Universities, 185 State Private universities, 129 Deemed to be Universities, 51 Institutions of National Importance under MHRD and four Institutions. The number of colleges has also registered manifold increase of 74 times with just 500 in 1950 growing to 37, 204 as on 31st March, 2013.

India holds an important place in the global education industry. The country has more than 1.4 million schools with over 227 million students enrolled and more than 36,000 higher education institutes. India has one of the largest higher education systems in the world. However, there is still a lot of potential for further development in the education system. The education sector in India has the witness for a major growth in the years to come as India will have world's largest tertiary-age population and second largest graduate talent pipeline globally by the end of 2020 . As of now the education market is worth US\$ 100 billion. Currently, higher education contributes 59.7 per cent of the market size, school education 38.1 per cent, pre-school segment 1.6 per cent, and technology and multi-media the remaining 0.6 per cent. Higher education system in India has undergone rapid expansion. Currently, India's higher education system is the largest in the world enrolling over 70 million students while in less than two decades, India has managed to create additional capacity for over 40 million students. At present, higher education sector witnesses spending of over Rs 46,200 crore (US\$ 6.96 billion), and it is expected to grow at an average annual rate of over 18 per cent to reach Rs 232,500 crore (US\$ 35.03 billion) in next 10 years. Some of the other factors acting as growth drivers to the Higher education sector are:-

- A booming economy and growing middle class

- Low GER in higher education ( 15\%) - the target GER of $30 \%$ by 2020 would mean 24 million new enrollments

- Increasing share of the services sector further emphasizes the role of education in developing manpower to global standards

- Several reforms by the government including the Education Bill are on the anvil to give a push to the education sector

- Foreign investment likely to come in with the passing of the Education Reforms Bill

\section{RECENT TRENDS IN THE HIGHER EDUCATION SECTOR}

Over the past few decades, the global economy has shifted from being manufacturing-centric to acknowledge-driven one and as countries move up the ladder of development, the contributions of hi-tech manufacturing and high value-added services to the GDP increases. Success in leveraging knowledge and innovation is only possible with a sound infrastructure of higher education. A successful education policy forms the foundation of all fields of national development including political, social, economic, technical, scientific and environmental. Thus, higher the quality of university education in a country; more prosperous and competitive are the people. Rohin Kapoor (2015) said that "With a rapidly flourishing workforce and the inevitable need for global acceptance, the internationalization of higher education has become critical to India's human resource growth. Foreign investment will play an instrumental role in strengthening India's higher education sector, both in terms of quality and access". 
- India's education sector offers a great opportunity with approximately 29 per cent of India's population being between the age group of 0-14 years.

- In 2014, with 29.63 million students and approximately 48,116 colleges and institutions, India's higher education segment is the largest in the world.

- It is expected to increase to US\$ 37.8 billion by 2020 .

- India has one of the largest networks of higher education institutions in the world with 666 universities and 39,671 colleges. It is also the third largest in terms of education enrolment with over 21.5 million enrolments per year.

- The private education sector which was valued at an estimated US\$ 96 billion in 2015 is estimated to reach US\$133 billion by 2020 .

- The Government of India has planned to provide enhanced access to higher education by creating two million additional seats for each age group, in the 12th Five-Year Plan.

- An advisory body, National Knowledge Commission (NKC) has been set up to guide policy and direct reforms, focusing on certain key areas such as education, science and technology, agriculture, industry and e-governance.

- It has also allowed 100 per cent Foreign Direct Investment (FDI) in the education sector through the automatic route since 2002.

- The total amount of foreign direct investments (FDI) inflow into the education sector in India stood at US\$ 1,171.10 million from April 2000 to June 2015, according to data released by Department of Industrial Policy and Promotion (DIPP).

- In the year 2015 government is expected to launch New Education Policy to address the changing dynamics in the education industry of the country as per the requirement of the population.

\section{ROLE OF EDUCATION AND ECONOMIC DEVELOPMENT}

In India, education is the key to the task of nation-building. It is also a well-accepted fact that providing the right knowledge and skills to the youth can ensure the overall national progress and economic growth. In a study by Dukkipati (2010) has stated that, "For India to maintain its economic growth in a global marketplace fueled by the knowledge economy, it needs to nearly double its number of students in higher education by 2012. Almost 51 per cent of India's population is under the age of 25 . Without proper access to education the country's demographic dividend could turn into a demographic disaster". The Indian education system recognizes the role of education in instilling the values of secularism, egalitarianism, respect for democratic traditions and civil liberties and the quest for justice. There is a huge demand for up gradation of education as India is expected to have a surplus of 47 million people in the working age group by 2020 .

Some of the earliest work in the economics of education argued that a major effect of more education is to improve the production capacity of the labour. Because highly educated workers are more literate and numerate, they should be easier to train to do more complex tasks. The human capital theory holds that investment in improving human resources via education, results in improved productivity and that both the costs of the investments and the benefits of improved productivity can be used to calculate an economic rate of return. The World Bank Policy Paper on Primary Education $(1990,1995,1999)$ embraced human capital theory, observing that education, particularly at the primary level increases the productivity of the workforce through 
improved literacy, numeracy and health status. Similarly, research on China reports evidence of the significant and positive relationship between higher levels of education and GDP using aggregate data at the national and provincial level (Fleischer, 2002:6). Estimates by Chen and Fang (2000) shows that, the stock of higher educated population has had a statistically significant positive and robust relationship to economic growth across provinces of China in the 1980s and 1990s. Wang and Yao (2002) found that, in 1978-99 investment in human capital contributed somewhat more than 10 percent to overall per capita growth of China (Fleisher, 2002:7).

According to World Bank's study (1991, extracted from Lopez et al, 1998:3) “education enriches people's understanding of themselves and the world. It improves the quality of their lives and leads to broad social benefits to individuals and society. It also raises people's productivity and creativity and promotes entrepreneurship and technological advances, demonstrated in countries from Malaysia to Ghana". Thus, the knowledge which received through higher education can be contributed to catching up with technologically advanced countries through the better use of modern technologies, developing new equipment and skills while expanding entrepreneurship with positive effects on job creation and spill-over the knowledge among co-workers. In addition, the improvement of the knowledge of the people leads not only to the economic growth but also to enhance the social development. As emphasized by Lopez et al (1998), no country has achieved economic development without investing in education development. Many studies have shown the high returns to basic education, research, training, learning-by-doing and capacitybuilding. Education is recognized as a principal contributory factor to boost the productivity of workers by generating skills that raise their working capacity, leading to economic growth (Hill et al, 2005:1; Bloom et al, 2006; Galiani et al, 2008:437). This productivity gains can be contributed to the enhancement of the income level of the individuals as well as the economy.

\section{CONCLUSION}

The development initiatives in many developing countries still continue to focus exclusively on basic education, seriously neglecting higher education. Sustainable socio-economic development implies that education systems focus on human capital as well as human development on economic growth as well as poverty reduction, on modern technologies as well as traditional methods, and on global as well as local concerns. Policy-makers must not only provide for basic education but also help to strengthen higher education. This will benefit society at large and have a positive effect on economic growth and development.

\section{REFERENCES}

[1] Castells M (1994) "The University System: Engine of Development in the new World Economy”, J Salmi \& A Verspoor (eds) Revitalizing Higher Education. Oxford: Pergamon, Pp.14-40.

[2] Chen, B. and Feng, Y. (2000) Determinants of Economic Growth in China: Private Enterprise, Education and Openness. China Economic Review 11 (1): 1-15

[3] Dukkipati, U. (2010). Higher Education in India: Sustaining Long-term Growth. In Center for Strategic Studies and International Studies, Washington D.C. Retrieved from http://csis.org/files/publication/sam_141.pdf 
[4] Fleischer, B. (2002) Higher Education in China: A Growth Paradox? Department of Economics, Ohio State University (mimeo).

[5] Incorporating Human Capital Accumulation, China Economic Review, 14, 1:32-52.

[6] Mark Bray, "Higher Education and Development", International Institute for Educational Planning, Vol. XXV, No-1, January-March 2007.

[7] Wang Yan and Yao Yudong (2002) Sources of China's Economic Growth 1952-1999.

[8] World Bank, (1990) Primary education: A World Bank Policy Paper, World Bank

[9] World Bank, (1995) Priorities and Strategies for Education: A World Bank Policy Paper, World Bank.

[10] World Bank, (1999) Education Sector Strategy: A World Bank Policy Paper, World Bank.

[11] http://www.ibef.org/industry/education-presentation

[12] http://articles.economictimes.indiatimes.com/2015-12-02/news/68717125_1_higher-

[13] education-sector-enrolment-universities

[14] http://indiainbusiness.nic.in/newdesign/index.php?param=industryservices_landing/359/ 2. 